\title{
The 5th International Conference on Evidence-based Policy in Long-term Care, Itävallassa (10.-12.9.2018)
}

Kolme päivää kestänyt pitkäaikaishoidon näyttöön perustuvaa politiikkaa käsittelevä konferenssi oli rakennettu kahden pääpuheenvuoron varaan ja suullisia esityksiä oli usean teeman alla. Kansainvälisessä konferenssissa oli varattu aikaa ja tilaa verkostoitumiselle kolmena päivänä oli mahdollista osallistua järjestettyyn iltaohjelmaan. Konferenssiin osallistujamäärä oli noin 150 henkilöä. Konferenssin järjestivät International Long-Term Care Policy Network ja WU Vienna University of Economics and Business (1).

\section{YLEISÖLUENNOT}

Ensimmäinen koko seminaariyleisön kokoavan luennon piti professori Douglas Wolf. Hän on väestötieteilijä, politiikkaanalyytikko ja gerontologinen tutkija, joka tutkii ikääntymisen, vammaisuuden ja pitkäaikaishoidon taloudellisia, väestöön liittyviä ja sosiaalisia näkökohtia USA:ssa. Luennon otsikko oli "Private and public provision of elder care: Can we find an equitable balance?" Esityksessä marssitettiin kuulijoiden eteen makrotaloudellisia analyyseja ja erilaisia maaesimerkkejä. Otsikon "private provision"-käsitteen kohdalla luennoitsija nauratti yleisöä rajaamalla käsitteen tarkoitta- maan perheenjäsenten tarjoamaa hoitoa, yksityistä sanan pelkistetyssä merkityksessä.

Professori Wolf kertoi, että Tanskassa on antelias poliittinen tahtotila pitkäaikaishoidon resursoinnille: palvelut perustuvat palvelua tarvitsevan henkilön toiveille ja tarpeille. Saksassa on vakuutuspohjainen järjestelmä pitkäaikaishoidossa, väestöstä noin 90 prosentilla on sosiaalivakuutus ja 10 prosentilla on yksityinen vakuutus. Pitkäaikaishoidon palveluiden saanti perustuu tarpeenarviointiin, jonka mukaisesti asiakas voi saada yhtä viidestä eri hoivapalvelun vaihtoehdosta. Saksalaiseen järjestelmään kuuluu, että uusinta-arvio asiakkaan tilasta ja hoidon tarpeesta toteutetaan puolivuosittain.

Saksassa paikallisen hallinnon tulkinnat ja päätökset hoivapalveluista ovat luoneet maan sisäistä variaatiota muistisairaiden vanhustenhoidossa. Professori Wolf suositteli käytäntöjen yhtenäistämistä kansallisella tai maakuntatasolla. Toisin sanoen hän suositteli paikallisorganisaatioiden päätösvallan vähentämistä ja suurempiin kokonaisuuksiin siirtymistä tutkimuksessa todetun alueellisen eriarvoisuuden vähentämiseksi.

Hän esitteli myös tutkimustuloksen, jonka mukaan muuttoliike suuriin kaupunkeihin vaikuttaa lasten mahdollisuuksiin osallistua ikäihmisten hoitoon, esim. Pohjois-Ruotsissa ei vanhuksilla ole lähellä asuvaa lasta, toisin kuin Etelä-Ruotsissa asuvilla ikätovereillaan. Itse mietin olisiko tilanne vastaava Suomessa?

USA:n hajanainen vakuutuspohjainen järjestelmä professori Wulfin mielestä ollut ylpeilyn aihe, vaan hän sanoitti sen hyvin niukaksi ja rikkinäiseksi "niin sanotuksi” järjestelmäksi. Medicare -vakuutus kattaa vain hyvin vähän pitkäaikaishoitoa ja Medicaid -vakuutuksesta pääsee osalliseksi vain hyvin rajatuin kriteerein. Niinpä pitkäaikaishoidostaan itse maksavat ovat niitä, joista on tulossa varattomia ja varattomuuskriteereiden täytyttyä he kuuluvat Medicaid-vakuutukseen.

Professori Wulf esitteli analyysin verojen kertymisestä koko elämän aikana lapsettomilla ja niillä, joilla oli lapsia. Tällä hetkellä verokertymä oli suurempi niillä yhdysvaltalaisilla, joilla oli lapsia. Hän suositteli politiikkamuutosta, jossa lapsettomat voisivat osallistua nykyistä enemmän verotulojen kerryttämiseen vanhuspalveluiden kustannusten kattamiseksi USA:ssa. Puhuja painotti, että haluaa sanoa ääneen niinkin yksinkertaisen asian kuin että perheenjäsenten tarjoamaa hoi- 
toa ei voi olla jos ei ole perheitä. Ja että väestötrendinä lapsettomuus on kasvussa. Yleisökeskustelun aikana tähän teemaan kohdistetun kysymyksen yhteydessä hän joutui tarkentamaan näkökulmaansa ja käytti vertausta flipperistä. Kuten flipperissä kuula edustaa sitä että on lapsia, jotka voisivat tarjota hoivaa vanhemmilleen, mutta pelin edetessä ei ole varmaa toteutuuko ylisukupolvinen hoiva.

Yleisö oli keskustelevaista ja ohjelman oli sopivan väljä, niin että keskustelulle jäi tilaan. Eräässä kommenttipuheenvuorossa todettiin, että usein asiakkaan puoliso tarjoaa hoivaa, eivät niinkään lapset ja tätä näkökulmaa ei esityksessä juuri tarkasteltu. Keskustelua ja näkökulmia esityksistä jaettiin myös \#ILPN2018 merkinnän avulla twitterissä.

Toisen pääpuhujan, apulaisprofessori Isabella Aboderin, otsikko oli "Toward 'fit-forpurpose' policy on long-term care in sub-Saharan Africa? Key challenges, approaches and opportunities". Hän johtaa Keniassa tutkimusyksikköä "Aging and Development Unit at the African Population and Health Research Center" (2). Hänen kuvauksensa Saharan eteläpuolisen Afrikan vanhojen ihmisten hoidon järjestämisestä rakentui osin omaelämäkerralliselle kertomukselle omasta isoäidistä, joka tullessaan vanhaksi ja heikoksi olisi halunnut asua kotonaan, sillä kodin lähipiirissä olivat hyvät ystävät ja tuttu naapurusto. Isoäidin toivomuksia ei voitu kuitenkaan toteuttaa ja hän joutui vastentahtoisesti muuttamaan poikansa perheeseen ja sieltä siirtymään vielä toiseen kaupunkiin tyttärensä perheeseen. Vaikka hoito saatiin järjestymään perhepiirissä, niin luennoitsija koki, että hän yhtenä lapsenlapsista ja sukulaista vain vieraili hetken isoäidin huoneessa. Todellisuudessa isoäidin viimeiset vuodet olivat yksinäisiä.

Apulaisprofessori Aboder muistutti, että väestöpolitiikan näkökulmasta Saharan eteläpuolisen Afrikka koostuu nuorista. Alle 25 -vuotiaita on $63 \%$ ja vain $5 \%$ väestöstä on yli 60 vuotiaita, mutta on huomattava, että osuudet eivät ole koko asia, vaan henkilöiden lukumäärä - ikääntyneitä ihmisiäkin on paljon. Kokonaisuudessa hoidon tarve kasvaa ja afrikkalaisen identiteettiin kuuluu se, että perhe tarjoaa hoivaa jäsenilleen. Usein naiset ovat hoivan tarjoajia, eivät välttämättä tyttäret, vaan miniät ja lapsenlapset. Perheen tarjoamassa hoivassa haasteet kuitenkin usein ylittävät mahdollisuudet, esimerkiksi jos ikäihmisen virtsanpidätyskyky on puutteellinen, on puhtaudesta vaikea huolehtia vaikka kaupunkiolosuhteissa puhdas vesi tulisi kotiin saakka. Hoivan tarjoajat ovat vaikeassa valintatilanteessa panostaako lasten vain ikäihmisen hoitoon. Kaiken kaikkiaan alueella tarvittaisiin tukea perheen tarjoamalle hoivalle. Perheperusteisten hoidon tukitarpeet eivät kuitenkaan ole nousseet keskiöön poliittisessa puheessa tai toiminnassa Saharan eteläpuolisessa Afrikassa, vaan lisääntymisterveyden haasteet ottavat leijonan osan väestöpolitiikan voimavaroista. Keniassa on tosin laadittu ikäihmisiä koskeva laki, mutta se on sanoitukseltaan hyvin vaikeatulkintainen. Esityksensä lopuksi luennoitsija listasi esteitä ja mahdollisuuksia ikäihmisten hoivan uudelleen järjestämiseen johtavista politiikoista ja päätteli, ettei politiikkalinjauksissa laitoshoitoa ja perheen tarjoamaa hoivaa pitäisi asettaa kahdeksi toisiaan poissulkeviksi vaihtoehdoiksi.

\section{SESSIO ESITYKSIÄ}

\section{HENKILÖSTÖ JA PITKÄAIKAISHOITO}

Amerikkalaisen Joan Hyden esityksen otsikko oli "Operational and Policy Implications of Recognition of Front Line Elder Care Workers' High-level Skills". Hyde tiivisti tekemänsä kirjallisuuskatsauksen tuloksia välitöntä hoitotyötä tekevän työntekijän toivottavista ominaisuuksista: myötätunto; sitoutuminen, ei tee työtä pelkästään saadakseen elantonsa, vaan on sitoutunut hoivatyöhön syvemmin; itseluottamus, hänellä on keinoja käsitellä sosiaalisesti hankalia tilanteita, joita tulee vastaan muistisairaita hoidettaessa. Hyden lista jatkui maininnalla siitä, että omakohtaiset hengelliset arvot auttavat työntekijää kohtaamaan kuoleman. Hän painotti, että asiakkaan elämänvaiheisiin ja persoonaan tutustuminen on laadukkaan hoitotyön edellytys vanhuspalveluissa.

Norjalainen Karen Christensen esitteli "Tactic Practicis over Time" esityksessään perheen sisällä toteutetun hoivan muutosta hoitotyöksi. Lainaten Søren Kierkegaardia hän määritti hoivan olevan sitä, että näkee toisen todellisuuden mahdollisuutena. Christensen erotti hoivan (care) ja hoitotyön (care work) eri käsitteiksi, joista hoitotyö yhdistyy hyvin- 
vointivaltioon. Ensimmäisessä vaiheessa vanhustenhoito oli emäntien elämänpiiriin kuuluvaa siinä missä lastenkasvatuskin. Myös kansalaisjärjestöt tuottivat osan palveluista. Toisessa vaiheessa maailmansotien jälkeen kunnat ryhtyvät tuottamaan vanhustenhoitopalveluja. 1960 -luvulta lähtien vanhustenhoitopalveluissa on lisätty kotihoitopainotteisuutta. Samaan aikaan on tapahtunut naisten työelämään siirtyminen muillakin aloilla. Kolmannessa vaiheessa, noin 1990-luvulta alkaen, kunnat ryhtyvät Norjassa tehostamaan palveluja. Tällöin asetettiin vanhuspalveluiden tavoitteeksi kotona asuminen niin pitkään kuin mahdollista. Samassa yhteydessä kotihoito medikalisoitui ja kotihoidon toiminta ei ollut enää kodin ylläpitoa, vaan sairaan asiakkaan hoitoa. New public management -ideat otettiin käyttöön kunnallisissa palveluissa ja esimerkiksi palvelujen ostamisessa otettiin käyttöön tilaaja-tuottaja -malli. Naiset olivat pääasiassa kotihoidon toteuttajia ja siis palkkatyössä. Kansalaisjärjestöt eivät juuri tarjoa palveluja, mutta kaupallisten toimijoiden markkinoille tulo on mahdollistettu.

Nykyisin Norjassa pitkäaikaishoidon toteuttamisessa ulkomaalaistaustaiset naiset toimivat henkilökohtaisina avustajina. Ongelmia on tunnistettu siinä, etteivät ulkomaalaistaustaiset työntekijät tiedä työelämän sääntöjä, ja tekevät asiakkaan kotona toteutetussa työssä korvauksetta ylityötä ja mahdollisesti enemmän kodin ylläpitoon liittyviä tehtäviä kuin mitä hoitotyötä sisältävään työsopimukseen kuuluisi. Christensen arvioi ulkomaalaistaustaisten työntekijöiden edunvalvontataidot heikoiksi.

Saksalainen Theobald Hildegard esitteli tutkimustuloksia otsikolla "The interaction of migration status and skill level in professional long-term care work in Germany: A multi-level intersectional approach". Saksassa ulkomaalaistaustaiset hoitajat matalalla koulutustaustalla tekivät ylityötä ilman korvausta, eivätkä ehkä osanneet rajata esim. siivoustehtäviä työnsä ulkopuolelle. Tämä oli hyvin tavallista niiden keskuudessa, jotka tekivät osa-aikatyötä esim. 20 tuntia viikossa. Jos ulkomaalaistaustaisella työntekijällä ei ollut juuri koulutusta, niin syrjintä työyhteisössä oli todennäköisempää. Jos koulutustausta oli vahva, kuten sairaanhoitajilla, niin ulkomaalaistaustaisten henkilöiden kokemus syrjityiksi tulemisesta työyhteisössä ei ollut sen todennäköisempää kuin muillakaan sairaanhoitajilla. Ulkomaalaistaustaisten hoitajien kohdalla esitettiin myös huoli työpaikkakoulutuksiin pääsemisen korkeasta kynnyksestä.

Samoin kuin selvityksessämme suomalaisessa vanhuspalveluissa (3) työntekijät saksalaisissa pitkäaikaishoidonlaitoksissa kokivat asiakkaiden taholta väkivaltaa, mutta kotihoidossa ei tätä ongelmaa ollut. Hildegard tähdensi, että asiakkaiden taholta koettu väkivalta liittyi ainakin kiireeseen ja heikkoon kommunikaatioon, ja ulkomaalaistaustaisilla puutteellinen kielitaito voi aiheuttaa konfliktitilanteita muistisairaan hoitotyössä. Hän kertoi, että Ruotsissa asiakkaiden taholta koettua väkivaltaa on raportoitu vähem- män ja eroja on selitetty Ruotsin suuremmalla hoitajamitoituksella.

Yleisökysymys herätteli pohtimaan, onko nuoria tulossa hoitoalalle. Christensen kertoi, että ala ei kiinnosta nuoria Norjassa, mutta maassa on toteutettu alalle valmistavia muuntokoulutuksia iäkkäämmille ihmisille. Hildegard totesi, että Saksassa sairaanhoitajan ammatti on houkuttelevampi kuin vanhustenhoitajan, koska sairaanhoitajana on enemmän mahdollisuuksia valita missä työskentelee. Myös sairaanhoitajan palkka on parempi ja vanhustenhoitajan palkalla on vaikea tulla toimeen, ainakin jos on perhettä. Sairaanhoitajan ammattikoulutus on Saksassa siirretty yliopistoon, mikä on lisännyt nuorten kiinnostusta alaan.

\section{TEKNOLOGIA JA PITKÄAIKAISHOITO}

Andrea Rotolo kertoi esityksessään miten teknologia on otettu käyttöön Italialaisessa pitkäaikaishoidossa "Introducing technological innovations in ageing societies: care providers' perspective". Tutkimusryhmä oli kartoittanut tilannetta vanhuspalveluiden tarjoajilta siitä, millaista teknologiaa oli otettu käyttöön. Erilaisia teknologisia ratkaisuja olivat mobiilisovellukset, esineiden internet, tekoäly, koneoppiminen, robotit, virtuaalitodellisuus, lisätty todellisuus, 3D tulostus ja puettava teknologia. Muotoilun ja teknologian aloja edustavalle tutkimusryhmälle oli ollut pettymys, että tutkituista organisaatiosta vain puolessa oli otettu käyttöön uutta teknologiaa. Käyttöön otettu teknologia edusti mobiilisovelluksia ja 
internetselainpohjaisia sovelluksia, siis teknisessä mielessä jo koeteltua ja vanhaa.

Yleisökysymyksissä todettiin, ettei esityksessä listattu teknologia kohtaa pitkäaikaishoidon haastetta, joka liittyy paljon käsityövoittoiseen perushoitoon ja työn ergonomiseen kuormittavuuteen. Vahvasti käyttäjälähtöistä kehittämistyötä esiteltiin konferenssissa muutamassa muussa teknologia-aiheisessa esityksessä.

Helene Riess USA:sta esitteli laadullisessa tutkimuksessa havainnollisin kalvoin kokemuksia turvarannekepalvelusta. Esitys oli otsikoitu: "I'm not ready yet" - Intra- and Interpersonal Adoption Processes of Personal Emergency Response Systems among Older Adults”. Tämän laadullisen tutkimuksen mukaan osa vanhuksista oli ottanut palvelun käyttöön "kapteenin käskyllä", osa oli ryhtynyt käyttäjiksi "valmentajan tsemppauksella" tai kumppanuudella, kun "kaverikin käyttää". Toisinaan käyttöönottoa hidasti vuosikausiakin sosiaalisen leimaantumisen pelko. Riess korosti, että teknologian suunnittelijoiden olisi hyvä ymmärtää mitä teknologian käyttö merkitsee käyttäjälleen; ei ole helppo ottaa käyttöön hälytyspalvelua, jos sen koetaan leimaavan käyttäjänsä surkuteltavaksi olennoksi. Yleisökommentissa todettiin, että yleisimmin kaatumiset tapahtuvat suihkussa tai heti sen jälkeen ja silloin juuri hälytin, olipa se rannekkeessa tai kaulanauhassa, on otettu pois, koska märkinä niitä on ikävä käyttää. Pelkkä teknologia ei siis valitettavasti ratkaise heikentyneen toimintakyvyn tuomaa kohon- nutta riskiä kaatumistapaturmille kotona.

Hongsoo Kim esitteli vakuuttavasti teknologia-avusteisen terveyshyötymallista elementtejä saaneen SPEC-mallin käyttöönottoa hoitokodissa Etelä-Koreassa. Esityksen otsikko oli "The Effectiveness and Technology Acceptance of an ICT-Enhanced Integrated Care Model for Nursing Home Residents in Korea: Evidence from the Systems for Person-Centered Elder Care -study”. Kim kertoi hoitokoteihin sovelletun teknologia-avusteisen, moniammatillisen integroidun hoidon hallintamallin hyväksymiseen ja tehokkuuteen liittyvistä tutkimustuloksista. Henkilökunta kirjasi potilaan hoitoa tabletilla. Hoitosuunnitelman tekeminen ja hoitosuunnitelman säännöllinen päivittäminen moniammatillisena ryhmätyöskentelynä muodostivat keskeisen osan potilaan hoitoa.

Teknologian hyväksymistä henkilökunnassa mitattiin pitkään käytössä olleella teknologian hyväksymistä mittaavalla mittarilla (TAM, technology acceptance model). Hoidon laadun arviointi oli toteutettu mm. RAI:lla (resident assessment instrument) ja tämä laadun seuraamiseen ja arviointiin tarkoitettu järjestelmä on laajasti käytössä suomalaisissakin pitkäaikaishoidonpalveluissa. Kim summasi tutkimuksen tuloksia: lyhytaikaisessa seurannassa (3 kk) hoidon laatu parani useilla eri ulottuvuuksilla. Henkilökunta kuitenkin arvioi teknologiasovelluksen helppokäyttöisyyden puutteelliseksi. Esityksen kuunneltua jäi vaikutelma, että tämän tutkijan jul- kaisuja kannattaisi seurata esimerkiksi Harvardin yliopiston sivuilta (4).

\section{LAATU JA JÄRJESTELMÄMUUTOKSET PITKÄAIKAISHOIDOSSA}

Pamela Nadash esitteli sulavasti hoitokotien arviointijärjestelmää Yhdysvalloissa. Esitys oli otsikoitu "A National-Level Analysis of the Relationship between Nursing Home Satisfaction and Quality in the US". Kaikki Medicare tai Mediaid vakuutuksesta varoja saavat hoitokodit ovat arviointijärjestelmässä. Arviointitiedot ovat internetissä nykyään viiden tähden järjestelmässä, aikaisemmin, ennen vuotta 2008, samat tiedot olivat kuluttajalle vaikeammin ymmärrettävässä muodossa. Kun viidentähdenjärjestelmä lanseerattiin käyttöön, yhden tähden hoitokodit menettivät kahdeksan prosenttia markkinaosuudestaan ja viiden tähden hoitokodit voittivat kuusi prosenttia markkinaosuudesta. Yhden tähden lisäys merkitsi noin viiden prosentin markkinaosuuden nousua.

Palveluntuottaja ovat hyvin tietoisia arviointitiedon olemassa olosta ja huomioivat sen toiminnassaan. Esityksessään Nadash esitti huolen siitä, että hoitokodit valitsivat potilaita, jotka olisivat vähemmän sairaita. Esimerkiksi sellaisia potilaita, joilla ei ole pitkäaikaista hoitamatonta kipua. Asiakkaiden mahdollisuuksissa valita hoitokoti on todettu olevan sosioekonomisia eroja. Vähävaraiset halusivat lähellä kotia oleviin paikkoihin, mutta Medicaid -vakuutuksesta rahoitusta saavissa hoitokodeissa on ollut pulaa hoitopaikoista. Asiakkaat 
käyttävät arviointitietoa hoitopaikan valintaan ja tuottajat ovat tietoisia arvioista. Nadash kertoi, että insentiivejä pitää säätää jatkuvasti, ettei palvelun tuottajien kesken tule kerman kuorintaa tai jos sitä esiintyy, niin siihen voidaan puuttua.

Edelliseen esityksen jatkona Tamara Konetzka kertoi siitä, mitä on opittu hoitokotien vertailusta. Esitys oli otsikoitu:"Two Decades of Nursing Home Compare: What Have We Learned?" Toisinaan palvelujen laatua arvioitaessa kyseenalaistetaan se miksi mitata asiakkaan tyytyväisyyttä. Konetzka muistutti, että on hyvä huomata, että asiakkaan antama tyytyväisyysarvio on eri asia kuin hoidon laatu. Tyytyväisyyttä on tarpeen mitata, jotta saadaan vastinetta läpinäkyvyyden periaatteeseen palveluista. Asiakkaan tyytyväisyyden arvioinnin suhteen on kuitenkin esitetty kritiikkiä: siinä ei ole variaatiota, asiakkaan ennakkoodotukset vaikuttavat, asiakkaan käytössä olevat coping keinot vaikuttavat, sosiaalinen hyväksyttävyys vaikuttaa jne. On kuitenkin olemassa tutkimusnäyttöä siitä, että korkea asiakastyytyväisyys korreloi positiivisesti hyviin hoitotuloksiin.

Asiakkaiden tyytyväisyyttä mittaavia kyselyjä on olemassa: lyhyitä, pidempiä, pitkäaikaispotilaille tai lyhytaikaisessa ja kertaluonteisessa hoidossa oleville suunnattuja. Konetzka kysyi tulisiko hallinnon kerätä asiakastyytyväisyystietoa? Ja jos sitä mitataan, niin mitä asioita tyytyväisyydessä pitäisi kysyä hoitokodeissa asiakkailta tai heidän omaisiltaan. Yhdysvalloissa mitattiin hoito- kodeissa asiakkaiden elämänlaatua, hoidon laatua, palvelun laatua, yleistä tyytyväisyyttä ja sitä, suositteleeko hoitokotia toiselle. Näitä tyytyväisyysmittausten tuloksia verrattiin hoitokotien tähtiluokitukseen, jossa paras tulos oli viisi tähteä. Selvityksessä todettiin, että hyvä asiakastyytyväisyys korreloi positiivisesti viidentähdenluokitukseen, mutta elämänlaadun kokemus ei ollut yhteydessä viidentähdenluokitukseen. Kaiken kaikkiaan asiakastyytyväisyysmittauksesta jäi paljon selittämätöntä osuutta, kun sitä yritettiin mallintaa hoitokodista annetulla arvioilla. Henkilökunnan koulutustasolla oli vaikutusta perheen antamiin arvioihin hoidosta.

Ismo Linnosmaa ja Pär Schön pitivät yhteisesityksen ostikolla: "Integration and Freedom of Choice in Care for Older People in Sweden and Finland - Compatible Policy Options?" Schön kaipasi lisää tutkimusta Ruotsissa tehdystä politiikkamuutoksesta. Hänen viestinsä oli: älkää Suomessa kopioiko meidän virheitämme, varsinkaan kun politiikkamuutoksia ei ole arvioitu riittävästi. Nykyisellään vaikuttaa siltä, että valinnanvapaus on lisännyt hoitokäyntejä perusterveydenhuollossa, erityisesti varakkaan väestönosan keskuudessa, jossa todennäköisesti on vähäisempi hoidon tarve. Schön sanoitti politiikkamuutosta jopa niin, että valinnanvapaus on aiheuttanut palvelujärjestelmän romahtamisen. Romahdusta koetetaan maakunnissa ja organisaatiotasolla hallita edes jollain lailla, esimerkiksi kaikkein sairaimmille potilaille ehdotetaan, et- tä valitse tämä palvelukattaus, jossa voidaan taata hoidon integraatio.

\section{OMAISET JA HOIVA}

Klara Lorenz esitteli Englannissa toteutettua tutkimusta "The well-being of unpaid carers of people with dementia - how husbands, wives, daughters and sons conceptualise well-being". Loppupäätelmissä hän alleviivasi, että on tärkeää että muistisairautta sairastavan läheinen saa myös omaa aikaa. Jos perusterveydenhuollon lääkäri tukee muistisairaan lähipiiriä, myös läheisen hoidossa tapahtuvat asiat tuntuvat paremmin hallittavilta. Mutta jos perusterveydenhuollon lääkärin tuki puuttuu, hoivaa antavat läheiset eivät voi yhtä hyvin. Ainakin englantilaisessa terveydenhuollossa perusterveydenhuollon lääkärillä on portinvartijan rooli muistisairautta sairastavan henkilön hoidossa, sillä lääkärin päätösten perusteella muodostuu pääsy sosiaalipalveluiden piiriin.

Väliajoilla oli mahdollista keskustella. Aija Kettuselle tulin ihmetelleeksi ääneen että äkkiseltään käsitteen "informal care" olisi luullut olevan kansalaisorganisaatioissa toimivien vapaaehtoisten tarjoamaa "epävirallista hoivaa", mutta toimijoina olivatkin puoliso tai lapset. Suomessa arkikielessä puhutaan omaishoidosta tai omaisen hoitamisesta. Keskustelukumppanini kertoi, että käsite ei ole englanniksikaan niin vakiintunut, vaan sen sisällöstä oli keskusteltu vuolaasti sessiossa. Suomessa taas keskustelua voi hämmentää se, että etuuksien ja viranomaisten näkökulmasta omaishoito 
käsittää vain ne henkilöt, jotka ovat tehneet sopimuksen omaishoidosta hoidettavan kotikunnan kanssa. Käytännössä omaishoidolla pyritään korvaamaan osa sosiaali- ja terveyspalvelujärjestelmän palveluista. Kettunen on ollut mukana selvittämässä omaishoidon kustannuksia ja arvioimassa hoivavapaa menettelyä (5).

\section{LISÄÄ TIETOA ILPN-VERKOSTOSTA JA KONFERENSSIIN OSALLISTUJIEN KOKEMUKSIA}

Saatuani kuulla, että esitys vanhuspalveluiden henkilöstön työpaikan vaihtoaikeista oli hyväksytty esitettäväksi ILPN -konferenssissa, päätin tutustua konferenssia järjestävään verkostoon tarkemmin. Ilpnetwork.org -sivustolta kuuntelin "Kymmen minuuttia ILPN kanssa" otsikon alle koottuja haastatteluja eri maista. Kun olin harjumaisemissa kuunnellut toistakymmentä esitystä, rupesivat mustikkarasiat olemaan täysiä ja minulle oli tullut selväksi, että tietyt kipukohdat pitkäaikaishoidon järjestämisessä toistuivat maasta toiseen. Tällaisia olivat alan vähäinen kiinnostavuus, työvoiman saatavuus, ikääntyvän Euroopan hoivapalveluiden tarpeen lisääntyminen, rahoitusvaikeudet kansallisella tasolla, ulkomaalaistaustaisten työntekijöiden osaaminen ja työolot, perheen ja läheisten tarjoama hoito sekä harmaan työvoiman käyttäminen kotona tapahtuvassa hoidossa. Vaikka osa haastatteluista oli jo muutaman vuoden takaa, olivat nämä teemat esillä myös konferenssin ohjelmassa.

Rinnakkaisohjelmaa oli konferenssissa paljon. Suurin osa suomalaisista esityksistä oli samaan aikaan. Uteliaisuudesta ja "kymmenen minuuttia ILPN kanssa" -haastatteluista innostuneena päätin pyytää muutamaa kollegaa vastaamaan kysymyksiini. Lopuksi kollegoiden näkemyksiä konferenssista. Kiitos Päivi, Aija, Lien ja Leena!

1. Lyhyt esittely, kuka olet ja mikä sai sinut osallistumaan ILPN konferenssiin

2. Jos pidit esityksen, niin kerro esityksesi otsikko ja lyhyesti mitä toivoisit yleisön siitä muistavan.

3. Kenelle voisit suositella konferenssia?

4. Mikä on ollut konferenssin anti sinulle ja työllesi?

1. Olen Päivi Luna, johtava asiantuntija Finanssiala ry:stä, vastaan hyvinvoinnin rahoituksen kärkihankkeemme kysymyksistä, jotka saivat minut tulemaan ILPN verkoston pariin jo sen synnystä lähtien. Erityisesti hoivan järjestäminen ja rahoitus ovat olleet mielenkiinnonkohteita työssäni jo pitkään. Verkoston tapahtuma, ILPN konferenssi tarjoaa oivallisen tilaisuuden keskustella ja tutustua alan laadukkaaseen kansainväliseen tutkimukseen. ILPN konferenssit ovat inspiraation lähde!

2. En pitänyt esitystä, mutta osallistuin keskusteluun $\mathrm{mm}$. ikääntyneiden palveluneuvonnan kehittämisestä ja talouslukutaidon sekä osaamisen huomioimisesta palvelujen ja niiden rahoituksen ja toisaalta myös rahoituspalveluiden asiakaspalvelutilanteissa. Kerroin myös FA:ssa tekemästämme yhteis- työaloitteesta, jonka pohjalta käynnistettiin seniorijärjestöjen kanssa prosessi lähetetyöpajoineen ja raportteineen, joiden avulla viedään havaittuja kehityskohteita ja pulmia eteenpäin ja esitetään ratkaisuehdotuksia sekä pohditaan yhteistyön avulla eri toimijoiden roolia ko. asian osalta ja mitä voitaisiin asian hyväksi tehdä paremmin kunkin toimijan toimesta, kuten järjestöt, kaupunki, yritykset ja ministeriöt yleensä. Vanhusneuvostot ja ikääntyneiden järjestöt olivat tässä olleet aloitteellisia meidän suuntamme, kun kysymyksessä on ikääntyneiden taloudellinen varautuminen, mihin sisältyvät hyvinvoinnin rahoitus, asuminen, digitalisaatio ja teknologia, turvallisuus sekä palvelujen ostaminen ja myyminen. Olemme olleet kehittämässä myös ikääntyneiden talouden hallintaa havainnoivaa sovellusta "My Financial Future", joka visuaalisesti havainnoi sekä opettaa taloudellisten tilanteiden muutoksista hyvinvoinnin erilaisilla poluilla ja simuloi mahdollisia vaihtoehtoja elinikään saakka. Ikääntyneiden julkisen ja yksityisen palveluneuvontaa on hyvä kehittää yhteistyössä.

3. Suosittelen konferenssia kaikille ikääntyneiden hyvinvoinnin tulevaisuuteen varautumisesta kiinnostuneille, tutkijoille, asiantuntijoille, vaikuttajille.

4. Lukuisat hyvät kontaktit ja mieleenpainuvat tieteelliset esitykset sekä keskustelut, joista on saanut virikkeitä töiden kanssa. Tutkimuksen asiantuntijoilla on myös hyvin käytännölliset näkökulmat. 
1. Olen Aija Kettunen ja toimin TKI asiantuntijana (VTT) Diakonia-ammattikorkeakoulun (Diak) Pieksämäen-kampuksella.

Olen vuosia kuulunut Diakissa asiantuntija-/tutkijaryhmään, jossa on terveystalous- ja yhteiskuntatieteilijöitä ja joka on kehittänyt sosiaalitalouden lähestymistapaa sekä käyttänyt sosiaalitaloutta ja terveystaloustiedettä hankkeissa, soveltavassa tutkimuksessa ja opetuksessa. Tavoitteena on nykyistä vahvemmin näyttöön ja tietoon perustuva sosiaalialan kehittäminen ja päätöksenteko. Yksi kohdealue on pitkäaikaisesti hoivaa tarvitsevien - jotka ovat usein vanhoja ihmisiä, mutta eivät aina - palvelujen järjestäminen siten, että hoivan tarvitsijoille saadaan hyvinvointia mahdollisimman paljon suhteessa toiminnasta eri tahoille aiheutuviin kustannuksiin. Tällöin tarkastellaan toimintaa, vaikutuksia ja kustannuksia, niihin vaikuttavia seikkoja ja organisoitumista sekä kustannusten ja vaikutusten jakautumista.

Suomessa on harvassa ryhmiä, jotka tutkivat pitkäaikaishoivaa tai sosiaalialaa tästä näkökulmasta. Sen sijaan Britanniassa, erityisesti Englannissa tällaista tutkimusta tehty jo 1980-90-luvulta lähtien. ILNPverkosto ja konferenssi on pitkälti juuri näiden brittiläisten tutkijoiden kokoama ja ylläpitämä.

ILPN-verkosto ja konferenssi tarkastelevat pitkäaikaishoivaa yleisemmin - ei vain sosiaali- ja terveystalouden näkökulmasta - ja verkostoon kuuluu ja ILPN-konferenssissa käy "saman henkisiä" pitkäaikaishoivasta ja sen järjestämi- sestä kiinnostuneita tutkijoita eri puolilta maailmaa.

2. Pidin esityksen omaishoitoa käsittelevässä työryhmässä ja otsikko oli "Supporting Informal care: Testing Feasibility of the ICECAP CES and the ASCOT Carer SCT4 Measures as a Part of Care Practice". Kerroin esityksessäni pilotista ja toimintatutkimuksesta, joka oli osa Etelä-Savossa toteutettavaa omaishoitoa kehittävää hanketta. Työ sai rahoituksensa ikäihmisten kotihoitoa ja omaishoitoa kehittävästä hallituksen I\&O-kärkihankkeesta. Tutkimusryhmään kuuluivat myös asiantuntijat Marina Steffansson Diakista sekä Maarit Karhula ja Sari Saukkonen Kaakkois-Suomen ammattikorkeakoulusta. Pilotissa kokeiltiin arviointivälineitä - mittareita - jotka osana omaishoidon tukihakemuksen käsittelyprosessia antavat tietoa omaishoitajan tuen tarpeesta ja hoivan kuormittavuudesta. Mittari auttaa myös seuraamaan omaishoidon kuormittavuuden muutosta eli tukevatko palvelut omaishoitotilannetta. Ollakseen käyttökelpoinen mittarin tulisi olla helppokäyttöinen sekä omaishoitajien että palveluohjaajien näkökulmasta. Pilotissa testattiin yhdessä Etelä-Savon sosiaali- ja terveyspalvelujen kuntayhtymän (ESSOTE) Mikkelin omaishoidon tukitiimin kanssa kahta tutkimukseen perustuvaa omaishoitajan elämänlaatumittaria (ASCOT SCT4 omaishoitajalle ja ICECAP kokemukset omaishoidosta). Pilotti osoitti, että kumpikin mittari oli sijoitettavissa omaishoidon tuen arviointiprosessiin ja ne systematisoivat sekä tukivat omaishoitoperheen tuen tarpeen arviointia ja tilanteen seurantaa. ESSOTE päätti valita pilotoiduista mittareista käyttöönsä ASCOTin. Sen lisäksi, että mittari antaa tietoa yksittäisten omaishoitajan elämänlaadusta palvelujen suunnittelun ja seurannan tueksi, kirjattaessa tiedot järjestelmiin, josta ne ovat saatavissa ryhmätasoisesti, vahvistuvat myös tietojohtamisen edellytykset. Palveluilla aikaan saatavan muutoksen sekä tausta- ja palvelutietojen kirjaaminen lisää myös edellytyksiä paljon puhutun vaikuttavuuden tutkimiseen. Jos myös luotettavia kustannustietoja on saatavana, vahvistuvat kustannus-vaikuttavuuden arvioinnin edellytykset.

3. Konferenssi soveltuu tutkijoille, jotka ovat kiinnostuneita pitkäaikaishoivasta tai tutkivat sitä sekä sosiaali- ja terveysalan ammattilaisille ja päätöksentekijöille, jotka ovat kiinnostuneita näyttöön ja tietoon perustuvasta pitkäaikaishoivan järjestämisestä ja toteuttamisesta hallinnon ja toteuttamisen eri tasoilla. ILPN-verkoston piirissä tehdään tutkimusta, joka tukee käytännön työtä ja päätöksentekoa. Aikaisemmilla kerroilla - joskaan ei tällä kerralla - mukana on ollut osallistujia esimerkiksi Sosiaali- ja terveysministeriöstä ja pääkaupunkiseudun kunnista.

4. Konferenssissa sain tietoa, jota voin hyödyntää työssäni. Lisäksi tuli esille, että Englannissa tutkitaan parhaillaan hieman samantyyppistä kysymystä, johon oma esitykseni liittyi. Myös 
Japanissa halutaan kehittää ASCOT-mittarin käyttöä osana omaishoitajien tukiprosessia. Konferenssin avasikin mahdollisuuksia kansainväliselle yhteistyölle jatkossa.

1. Olen Lien Nguyen, erikoistutkija/terveystaloustieteilijä Terveyden ja hyvinvoinnin laitoksesta. Olen ollut kolme vuotta kansainvälisessä EXCELC-tutkimushankkeessa (6). Hankkeen tutkijoilla oli ILPN 2018 kokouksessa monia esityksiä, joista yksi oli minulla.

2. Esitykseni otsikko oli "Introducing the ASCOT in Finland - Translation and Validation of the Instrument". Sosiaalipalvelujen vaikuttavuusmittarin siirrettävyys suomalaiseen kulttuuriin edellyttää standardoidun kääntämisprosessin. Ennen mittarin käyttöönottoa täytyisi suorittaa mittarin monikulttuurinen validointi, minkä jälkeen täytyy vielä varmistaa mittarin luotettavuus toistuvissa mittauksissa.

3. Suosittelen konferenssia pitkäaikaishoidosta tai pitkäishoivasta ja integraatiosta kiinnostuneille. Niille, jotka tekevät sosiaali- ja terveystalous- tai työn taloustieteellistä tutkimusta näistä teemoista sekä niille, jotka työskentelevät näiden teemojen parissa käytännössä.

4. ILPN-verkosto. Opin, että monet tutkimushankkeet ovat nykyään suuria yhteistyöhank- keita. Sain itselleni lisää tutkimusaiheita.

1. Olen Leena Forma, terveystaloustieteen yliopistonlehtori Tampereen yliopiston Yhteiskuntatieteiden tiedekunnasta. Olen tutkinut vanhojen ihmisten pitkäaikaishoidon käyttöä ja kustannuksia, ja lähdin konferenssiin kuulemaan, mitä pitkäaikaishoidon tutkimuksessa on meneillään, ja esittelemään omaa tutkimustani sekä verkostoitumaan muiden tutkijoiden kanssa. Osallistuin syksyllä 2016 Lontoossa järjestettyyn ILPN-konferenssiin, ja se oli antoisa.

\section{Esitykseni otsikko oli "Is} closeness of death a determinant of long-term care use among the oldest old?” Päätulos oli, että ikä ja kuoleman läheisyys määrittävät pitkäaikaishoidon käyttöä myös 90 vuotta täyttäneillä. Kun tarvetekijät (toimintakyvyn vajausten määrä, dementiadiagnoosi ja muiden diagnoosien määrä) vakioitiin, kuoleman läheisyys ei ollut enää merkitsevästi yhteydessä pitkäaikaishoidon käyttöön.

\section{Suosittelen konferenssia paitsi} alan tutkijoille, myös niille, jotka käytännössä suunnittelevat pitkäaikaishoitoa ja tekevät sen järjestämiseen liittyviä suosituksia ja päätöksiä.

4. Konferenssista sain inspiraatiota omaan tutkimukseen.

\section{KIITOKSET JA VASTUUNRAJAUS}

Kiitän kongressimatkan rahoituksesta Sosiaalilääketieteen yhdistystä ja Terveyden ja hyvinvoinnin laitosta (THL).

Kirjoituksessa esitetyt näkemykset eivät edusta Sosiaalilääketieteen yhdistyksen tai THL:n näkemyksiä ja tekstissä mahdollisesti olevat virheet ovat omiani.

\section{LÄHTEET:}

(1) International Conference on Evidence-based Policy in Longterm Care sivusto (ilpnetwork.org) 1.10.2018.

(2) Aging and Development Unit at the African Population and Health Research Center (aphrc.org) 1.10.2018.

(3) Josefsson, K; Sinervo T; Vehko, T: Asiakkaiden hoitajiin kohdistama väkivalta vanhustyössä. THL, Tutkimuksesta tiiviisti 9/2018. Helsinki. http://urn.fi/:URN: ISBN:978-952-343-101-0

(4) Harvard, School of Public Health, henkilösivu Hongsoo Kim (hsph.harvard.edu/ hongsoo-kim/) 1.10.2018.

(5) Shemeikka, R; Buchert, U; Pitkänen, S; Pehkonen-Elmi, T; Kettunen A: Omaishoitajien tarvitsemat tukitoimet tehtävässä selviytymiseen. Valtioneuvoston selvitys- ja tutkimustoiminnan julkaisuja. Valtioneuvoston kanslia 2017. Helsinki. http://tietokayttoon. fi/julkaisu?pubid=19101 1.10.2018

(6) Exploring Comparative Effectiveness and efficiency in Long-term care -hanke (https://www.excelc.eu/) 1.10.2018

\section{Tuulikki VehKo}

Erikoistutkija Sosiaali- ja terveydenhuollon tutkimus -yksikkö Terveyden ja hyvinvoinnin laitos 